Review Article

\title{
Overview of Different Rate of Nitrogen Application on Growth and Yield Components of Head Cabbage (Brassica oleracea. capitata L.) in Ethiopia
}

\author{
Damtew Atnafu \\ Department of Plant Science, Jinka University, Jinka, Ethiopia \\ Email address: \\ damtewatnafu@gmail.com
}

To cite this article:

Damtew Atnafu. Overview of Different Rate of Nitrogen Application on Growth and Yield Components of Head Cabbage (Brassica oleracea. capitata L.) in Ethiopia. American Journal of Life Sciences. Vol. 8, No. 6, 2020, pp. 196-200. doi: 10.11648/j.ajls.20200806.13

Received: May 27, 2020; Accepted: June 15, 2020; Published: November 23, 2020

\begin{abstract}
Cabbage is belongs to the family cruciferae and it is biennial crop with a very short stem supporting a mass of overlapping leaves to from a compact head. Ethiopia has a variety of vegetable crops grown in different agro- ecological zones by small farmers, mainly as a source of income and food. Commercial producers are also involved in the production, processing and marketing of vegetable. For this reason, it poses the most difficult problem in making fertilizer recommendations. Plant demand for nitrogen can be satisfied from a combination of soil and fertilizer to ensure optimum growth and yield of cabbage. The major essential plant nutrient nitrogen was found increasing in short supply in the soils. Nitrogen is required in much greater quantities than most other nutrients. It is an important component of proteins, enzymes and vitamins in plants, and is a central part of the essential photosynthetic molecules; chlorophyll. Plant demand for nitrogen can be satisfied from a combination of soil and fertilizer nitrogen to ensure optimum growth. Thus, it requires applying of appropriate rate of fertilizer for the enhanced cabbage productivity and sustainable yield. Many reviews on show that nitrogen application increases the total yield of cabbage also enhance. But this is possible as long as it is managed properly in terms of rate and time of application. Nitrogen levels have to be regulated to obtain high yield from cabbage. Hence, review on the further investigation need to be done up to the yield and extra year to come up comprehensive recommendation of optimum nitrogen application for the successful production of cabbage.
\end{abstract}

Keywords: Cabbage, Nitrogen Application, Yield

\section{Introduction}

Cabbage can grow easily under wide range of environmental condition in both temperate and tropical, but cool moist climate is most suitable [21]. Optimum growth occurs at a mean daily temperature of about 17 degrecentegrade with daily mean maximum of 24 degree centigrade and minimum of 10 degree centigrade. Mean relative humidity should be in the range of 60 and 90 percent [5].

Cabbage is grown for its head in more than ninety countries throughout the world [14]. The major cabbage growing countries of the world are china, India, South Korea, Germany, japan and South Africa [25]. Cabbage ranks fifth among the vegetable crops of the world. The area planted with headed cabbage worldwide in 2009 was estimated at about 3.2 million hectare in 124 countries production some.
In the same year, area planted by cabbage was about 2.5 million hectare in Asia, 0.5 million hectare in Europe, 80,000 hectare in America and 120,000 hectare in Africa [17]. In Africa a total of 2 million tons were produced in 2008 and it has shown an increase by $20 \%$ over the 10 -year period between 1998 and 2008. The five cabbage producer African countries are Kenya, Egypt, Ethiopia, Niger and South Africa and these five countries have maintained the dominance of the sector throughout this period. Ethiopia accounted for $12 \%$ of the total production in Africa [29]. area, production and yield of head cabbage in Ethiopia 2007/2008 were 1989 hectares, 11,765 tons and 5.9 t/ha respectively. In 2008/2009 it grew to 3399 hectares 24,1334 tons and $7 \mathrm{t} /$ ha respectively. Within these two years the area has increased by $70 \%$ whereas the production has increased by $105 \%$. In south Regional state the area covered by head 
cabbage in year 2008/2009 was 2188.9 hectares while the production was 15,601.9 ton and the yield is $7 \mathrm{t} / \mathrm{ha}$ [1].

The world average yield is $10-40 \mathrm{t} / \mathrm{ha}$. The average cabbage yield of national as well as farmers around our country is very low when compare to the world average. The major factors for the low productivity of this cabbage in Ethiopia. Its quality is also poor. Some cabbage heads are very small where are other are very big, cracked, burst rotten and loose heads which are fewer acceptances in the market. In general crop production can be increased either by improving inherent genetic potential of the crop or trough application of better agronomic management such as fertilizer rate which contribute to substantial amount of crop [7]. The possibility of securing high yield depends much upon a proper consideration of optimum nitrogen rate per unit area and the pattern in which the given quantity of seeds or plant population is arranged in the field of planting [3]. This is due to the fact that the quantity of solar radiation, which penetrates a crop canopy greatly, depends on nitrogen rate and individual plant morphology [12].

Likewise, the plant density is problem among several production limiting factors in the study area. Nitrogen in one of the critical plant nutrients in cabbage growth and yield. It is significant to note that nitrogen response is directly associated to the soil type, emphasizing that soil varying in fertility status react differentially to the applied fertilizer [7]. Thus, it requires applying of appropriate rate of fertilizer for the enhanced cabbage productivity and to have good vegetative growth for sustainable yield. Many experiments show that nitrogen application increases the total yield of cabbage possible when managed properly in terms of rate and time of application [31].

Due to this they unable to maximize their income and improve livelihood. This intended to as to do this overview research so it is important to recommend the optimum nitrogen rate for growth and yield of cabbage by developing intensive agriculture to improve the income of farmers around this area. This review on the study is to assess the effects of different rate of nitrogen applications on growth and yield components of head cabbage.

\section{Distribution, Origin and Taxonomy of Cabbage}

Cabbage (Brassica oleracea, varcapitata) is also known as Cole crops. It belongs to family Brassicaceae (Cruciferae) and generally referred as Brassicas. It is important groups of crop worldwide. It is originated from Western Europe and Northern Shore of Mediterranean region where it has been grown for more than 3000 years and its chromosome number is $2 n=18$. The genus Brassica includes about 100 species majority of which are native to Mediterranean region. The crop is attributed to the Mediterranean centre of origin. It is widely grown as cool-season crop and is very popular with gardeners [21]. It is dicotyledonous biennial crop, but it is grown as annual. In the first season growth it produces the head and in the second it produces seeds. Cabbage form several different head shapes: pointed, conical or oblong, round or drummed shaped. Cabbage generally classified as headed which is round, oval or flat. Chinese head cabbage is oval and flat, moreover it is loosely formed and light in weight Head formation in cabbage is quantitative trait controlled additively with low dominance effect. It is only head cabbage that changes in leaf shape becoming wider because of the shorter petiole length with increasing leaf position and thus cabbage acquired the developmental change in leaves. Cabbage has been domesticated and used for human consumption since the earliest antiquity [26].

\subsection{Nutritional Importance of Cabbage}

Cabbage is known for its nutritional importance and it is rich in mineral and vitamins like A, B1, B2, and C. It is also known for it is cooling effect being an appetizer, it aides digestion thereby help preventing constipation. It also protects against cancers [22]. Cabbage is grown for its leaves and commonly used as vegetable. Cabbage is an excellent source of mineral such as calcium, iron, sodium, Potassium and phosphorus. It has substantial amount of betta carotene, ascorbic acid and others. It has calories $(27 \%)$, fat $(0.1 \%)$ and carbohydrate $(4.6 \%$ it is good source of protein $(1.3 \%)$ which contains all essential amino acids; particularly sulfur containing amino acids [21].

A $100 \mathrm{~g}$ edible portion of cabbage contains $1.8 \mathrm{mg}$ protein, $0.1 \mathrm{mg}$ fat, $4.6 \mathrm{mg}$ carbohydrate, $0.6 \mathrm{~g}$ mineral, 29 calcium. $0.8 \mathrm{mg}$ iron and $14.1 \mathrm{mg}$ sodium [28]. The only part of the cabbage plant that is normally eaten by human being is the leafy head; more precisely, the spherical cluster of immature leaves, excluding the partially unfold outer leaves. Cabbage is used us row in salad such as coleslaw, as a cooked vegetable, or reserved in pickle or sauerkraut. Flavor in cabbage is due to the glycosides sinigrin [21]. Nitrogen is a primary (macro) nutrient which plays most important roles in legumes for theformation of amino acids which is the building blocks of protein. It is also important for celldivision and vital for plant growth [30]. Nitrogen is a chlorophyll component that promote vegetative growth and green coloration of foliage. It is also directly involved inphotosynthesis and is a necessary component of vitamins and aids in production and useof, carbohydrates and influence energy reactions in plants as well [24]. Nitrogen is, most commonly deficient nutrient among macro and micronutrients, besides considerableamount of nitrogen is removed from soil when protein, rich grain or hay is harvested [30].

\subsection{Cabbage Production in Ethiopia}

Ethiopia has a variety of vegetable crops grown in different agro- ecological zones by small farmers, mainly as a source of income and food. Commercial producers are also involved in the production, processing and marketing of vegetable [32]. These crops are produced under rain fed and irrigation conditions. It is produced both in cereals based cropping system and in monoculture. Largely cabbage is produced by 
irrigation rather than rain fed. At present different crops are produced in many home gardeners and also commercially in different parts of the country. But most of the production is by small holder. Cabbage production in Ethiopia is scattered in the high lands but the larger production is found at the central high lands of the country [2]. Other vegetables such as onion, garlic, shallot, capsicum, tomato, head cabbage, etc are produced by individual growers and others by private invertors as well as state enterprises. The most important cabbage varieties cultivated in Ethiopia are Copenhagen and Early drum head. Other warm season vegetables such as tomato, onion and capsicum are grown in lowland areas under irrigation, where as the high land areas offer favorable condition to grow cool season vegetable like cabbage, garlic, shallot, carrot, etc.

In Ethiopia, land holders living near urban centre largely practice vegetable farming. Most vegetables are not commonly practiced by the rural peasant holders [6]. Most of the vegetables produced in Ethiopia include cabbage are grown from imported seeds from various countries except limited once such as shallot, garlic, hot pepper and kale, which has been traditionally produced. The production of vegetables varies from cultivating a few plants in back yard, for home consumption to large scale production for the domestic and export markets. The crop can generally be very important source of vitamin, mineral, and protein to a country like Ethiopia where the people experience malnutrition due to heavy dependence on cereals. Its primary contribution in solving the health problem is through providing vitamins and minerals. As population increases, the needs for intensive agriculture becomes a paramount important to maximize out put to which vegetable are favorable. The marketing aspect of vegetables seed in the country including cabbage is heavily dependent on important source of seed. The seed market in the country is predominantly imported from abroad and only few importers are involved in the importation. the importation of seed and this has Influenced the national market [2].

\subsection{Cabbage Nutrient Requirement and Their Management}

The most important nutrient for cabbage is nitrogen, phosphorus and sodium molybdate. In cabbage fertilizers (especially nitrogen) promote rapid growth, high yield and high quality. High value crops such as cabbage, proper nutrition is important in order to produce a high yield and good quality [32]. There is a correlation between amount of nitrogen applied and quality of cabbage. Cabbage head will not form if there is shortage of nitrogen. On the other hand, excess nitrogen may cause the formation of loose heads with internal decay. The demand for phosphorus is greater during head formation and shortage will result in purple leaves. Potassium deficiency can cause cracked heads. Cabbage also requires sulfur, magnesium, and boron. High temperature causes nutrients, especially nitrogen, to be available to the growing plants much quicker and will result in high quality yields [26].

\subsection{The Role of Nitrogen in Cabbage}

The doubling of agricultural food production worldwide over the past four decades has been associated with increase in use of nitrogen fertilizer. As the consequence of, both the recent and future identification of the use of nitrogen fertilizer in agriculture already has and will continue to have major determinate impacts on agriculture [10]. Plant takes up nitrogen in the form of nitrate or ammonium from organic matter, inorganic matter and fixation of free nitrogen by microorganisms. Therefore, nitrogen is the motor of plant growth and being the essential constituent of protein is involved in all the major processes of plant development and yield formation. It stimulates vegetative growth and encourages the development of large stems and leaves.

Nitrogen tends to produce succulence, a quality of great important in many vegetables. A good nitrogen supply of the plant is also important for uptake of the other nutrients commonly supplied by fertilizers; nitrogen has the quickest and most pronounced effect. As natural soil nitrogen supply is rarely sufficient, growers usually apply nitrogen fertilizer in economically wasteful and can be lost to environment. An adequate supply of nitrogen is associated with vigorous vegetative growth and a deep green color. Since nitrogen favors growth, it may delay maturity of fruits and seeds. Excessive quantities of nitrogen can under some conditions prolong the growing period and delay crop maturity [16]. It is most likely to occur when adequate supplies of other plant nutrients are not present. Nitrogen deficiency can be prevented in the short term by using grass mowing mulch, or foliar feeding with manure, and in longer term by building up levels of organic matter in the soil Sowing green manure crops such as grazing rye to cover soil over the winter will help to prevent nitrogen leaching, while leguminous green manures such as winter tares will fix additional from the atmosphere [23].

\subsection{Rate of Nitrogen on Growth of Cabbage}

According to Everaarts and Mole [4] reported increasing uniformity with increasing amounts of nitrogen applied. In Cabbage production uniformity in head is important. Increase in relative length was observed when nitrogen application rate increases higher variation in plant height, leaf count, leaf area, whereas dry matter content of the head decreased depend on soil type. This was associated with softer head tissue at higher nitrogen availability, there by having less physical resistance to stalk elongation. He also observed decrease in percent dry mass of the heads, increased number of burst heads and increased tip burn in the head with increased nitrogen rate from $150 \mathrm{~kg} / \mathrm{ha}$ to $250 \mathrm{~kg} / \mathrm{ha}$. It was therefore concluded that higher nitrogen fertilizer of $200 \mathrm{~kg} /$ ha decreased the quality of cabbage heads on loam soil. To produce optimum yield of good quality head Cabbage, often high amount of nitrogen fertilizer are applied.

The recommended total amount of nitrogen fertilizer for cabbage are 160 to $260 \mathrm{~kg} / \mathrm{ha}$ (The Fertilizer Society of south Africa, 2000). In reality, the amount of nitrogen fertilizer used 
is probably higher as farmers may apply more fertilizer than recommended to secure yields (Claassens, personal communication, 2004). Head with and height increase with nitrogen fertilizer application. It has been accepted that application of nitrogen fertilizer increase yield, plant uniformity, and quality. An experiment conducted by [9] in Bangladesh to compare three levels of nitrogen fertilizer rate that applied in split $(60 \mathrm{~kg} / \mathrm{ha}, 120 \mathrm{~kg} / \mathrm{ha}$ and $180 \mathrm{~kg} / \mathrm{ha})$ on clay loam soil showed the maximum yield of head Cabbage $(65.11 \mathrm{t} / \mathrm{ha})$ were found from the plot receiving fertilizer rate of $180 \mathrm{~kg} / \mathrm{ha}$ nitrogen and $60 \mathrm{~kg} / \mathrm{ha}$.

\subsection{Effects of Different Rates of Nitrogen Application on Growth Components of Head Cabbage}

Plant height Many studies revealed that significance influence of nitrogen fertilizer on plant height as it plays vital role in vegetative growth of plants 20.067 a 8.93a. Similar result was reported by [11] found that plant growth were increased with increasing levels of nitrogen application. Similarly, [20] reported that plant height increased the increasing dose of nitrogen up to $260 \mathrm{~kg} / \mathrm{ha}$. Days of $50 \%$ head initiation early initiation of head was recorded from control this experiment was in contrary to [19] Reported that higher nitrogen level favoured the growth of plants with large leaf area and it was more usefully utilized in head formation. However the experiment was contract the result this author, it is because of it does not up taken the nutrient properly. Excessive quantities of nitrogen Can under some condition prolongs the growing period and delay maturity [16]. This is most likely to occur when adequate supplies of other plant nutrient are not present.

\subsection{Effects of Different Rates of Nitrogen Application on Yield Components of Head Cabbage}

Mean number leave per plant at physiological maturity was not significantly affected by nitrogen fertilizer. This is due to the fact that at maturity, Cabbage leave were folded and number of in folded leave was decreased, [18]. Leaf length Application of nitrogen fertilizer significantly influenced leaf length of Cabbage. The positive effect of nitrogen on leaf length might be due to its key role in the synthesis of Chlorophyll, enzymes and proteins, [8]. Leaf width Application nitrogen fertilizer at different rate showed significant effect on leaf width of Cabbage, [15]. Head diameter was significantly affected by application of different rates of nitrogen, [13] who reported, head diameter increased from $98 \mathrm{~mm}$ to $218 \mathrm{~mm}$ when the nitrogen level increased from 0 to $120 \mathrm{~kg} / \mathrm{ha}$, respectively

\section{Conclusion}

From this review, it can be concluded that nutrient elements focused in this study Nitrogen application influence crop quality. Cabbage is one of heavy feeder of plant nutrients including nitrogen, phosphorus, and potassium and it responses highly to nitrogen and moderate to phosphorus. Commercial producers are also involved in the production, processing and marketing of vegetable. For this reason, it poses the most difficult problem in making fertilizer recommendations. The amount of fertilizer applied is influenced by fertility status of the soil, soil type, moisture and temperature regimes, and the onset, intensity and duration of rain fall as well as irrigation facilities. The plant have high requirement of nitrogen. Nitrogen promote the growth and head formation, it is one of most important nutrient affecting the growth, development and quality of the plants. Cabbage producers must know the appropriate amount of nitrogen fertilizer by considering their local Condition. The growth and developmental Stage must be considered when nitrogen applied to match the nutrient plant demand. This is because of at maturity, Cabbage leave were folded and number of un folded leave was decreased. To understand considered in the review study the result of present indicated that the application of high rate of nitrogen found to be prep arable in growth components. To understanding, the review study was done the growth parameter was taken to review on assesses the effect of nitrogen rates on cabbage. Ethiopia has a variety of vegetable crops grown in different agro- ecological zones by small farmers, mainly as a source of income and food.

\section{Acknowledgements}

I would like to thanks Daniel keskes for helping in suggestion, comment and advise and also, thanks Jinka University to support laptop computer for this studies.

\section{References}

[1] CSA, 2008. Area and production of crops report, volume 121 , Addis sababa, Ethiopia.

[2] Dawit Alemu and Hailemariam Teklewold, (2004), marketing fruit and vegetables: Opportunities and Ethiopia.

[3] Endale, g. and Gebremedhin W, 2009. Effect of spatial arrangement on tuber yield of some potato cultivars. Afri. crop Sci. J. 9 (1): 67-76.

[4] Everaarts, A. P. and De Moel, C. P. 2007. The Effect of nitrogen and the medthod of application on yield and quality of white cabbage. European J. argon, 9: 203- 211.

[5] FAO, 2012. crop water information: Cabbage. J. of natural resource and envi. dep, 1: 991-2.

[6] Fekadu and dendena G. 2006. Review on status of vegetable crops production and Marketing in Ethiopia. Uganda j. of Agri. Sci, 12 (2): 26-30.

[7] Frezer A. 2007. Effect of planting density and nitrogen application on yield yield components of potato at enderta, southern tigray, Ethiopia. MSc. thesis presented to Harmony university. $p p$ 18-27.

[8] Hadfield, 2008. Evaluation of Cabbage Cultivar grown under organic compost and mixed mineral fertilizers. 
[9] Haquek. M. F Jahangir A. A. and M. E. Haque M. E. 2006. yield and quality of cabbage as affected by nitrogen and phosphorous fertilization. Bangladesh J. Sci. Ind. Res, 41 (1-2) 41-46.

[10] Hirel B. Jaeques Le gous, Betrand Ney and AnareGallas, 2007. The challenge of improving nitrogen use efficiency in crop plants. J. of experimenaltbotany, 58 (9): 2369-2387.

[11] Jaiswal (2002). Effects of nitrogen level, methods of applications and Spacing on growth and productivity of Cabbage.

[12] Jerry E. M., L. G. Cury, W. D. Demichele and N. D. Beker, 2006. Lighit penetration in Row.

[13] Keteseeman, 2006. Effect of age of seedling and nitrogen on growth and yield of Onion.

[14] Meena M. L, Ram R. B. Rubee L. and Shama S. R. R 2010. Determining Tied Components in Cabbage (Brassica oleraceavarcapitata L.) Trough Correlation and Path Analysis. International journal of science and nature. 1 (10): 27-30.

[15] Mengel K, Kirby EA (1987). Principles of plant nutrition. forth edition. international Potash institute, lPl, Bern, Switzer land.

[16] More K. 2006. Response of Cabbage Transplant to Nitrogen, phosphorous and potassium.

[17] Nina K. M 2011. Quality of Cabbage, Yield and potential risk of ground water nitrogen pollution, As affected by nitrogen fertilizer and irrigation. Journal science food agric, 92 (10): 92-98 nutrition. Msc, University of Pretoria, 12-24.

[18] Pankaj S (2006). Integrated effect of bio-inoculants, organic and inorganic fertilizer on growth and yield of Cabbage.

[19] Parmar et al (2009). Effects of Irrigation, Nitrogen, and Spacing on yield of Cabbage.

[20] Pramanik (2007). Effects of nitrogen and Phosphours on the growth and yield of Cabbage (Brassica oleracear. capit. L.).

[21] Rai, N and Asati, B. S, 2005. Correlation path coefficient analysis for the yield and its traits in cabbage. The Orissa J. of Hort. 33 (1): 31-34.
[22] Ruzawlah K. Sher a., Salimulah K., Fayan A., Mer Z and Bashir A, Kahan, 2002. Effect of different level of nitrogen, phosphorous and potassium on growth and yield of cabbage. Asian J. of plant sci., 1 (5): 548-549.

[23] Sanderson, K. R and Ivany. J. A. 2008. Cole crop yield response to reduce nitrogen rate. Can. J. plant, 79: 149-151.

[24] Sara, S., Morad, M. and Reza, C. M. 2013. Effect of nitrogen applicatio by, chlorophyll.

[25] Sarker, M. YAzad, A. K., HASUN. M. K, Nasreen. ANaher. Q and Baset, M. A. 2002 Effect of plant spacing and source of nitrities on the growth ang yield of cabbages. Pakistan J. of Bio. Sci., 5 (6): 636-639.

[26] Semuli. K L H. 2005. Nitrogen requirement for cabbage transplant and crop response to spacing and nitrogen top dressing. M. Sc. Thesis. University of Pretoria, South Africa. $32-42$.

[27] Simret, K/Yesus, Musa Jarso, Dibaba Damesa, Worku Burayu, Asrat Zena, 2004. Vegetable, root and tuber crops extension package manual. Un publishedmanual. Ministry of Agri.

[28] Singh, R. V and Naik, L. B. 2006. Response of cabbage to plant spacing, nitrogen and phosphorous levels. Indian J. Hort. 45: $325-328$.

[29] Statical Division, Food and agriculture Organization (SDFAO). 2010. Africa $J$. of the fertilizer Society Of South Africa, 2000. Fertilizer handbook. Beria Printers. Lynwood Ridge, South Africa.

[30] Uchida, R. 2000. Essential nutrients for plant growth: Nutrient functions and deficiency, symptoms. In: Plant nutrient management in Hawaii's soils. College of Tropical; Agriculture and Human Resources, University of Hawaii at Manoa: 31-55.

[31] Westeveld S. M. Donald M. R. and Mckeown. A. W. 2003. optimum nitrogen fertilization.

[32] Yebirzaf. Y. (2015). Effect of different rate of nitrogen fertilizer on the growth and yield of cabbage (Brassica Oleraceae) at Debre Markos, North West Ethiopia. Afri. J. Plant Sci Vol. 11 (7), pp. 276-281. 